Jakub Rawski

\section{Sexy Fascism: Exemplifying the Relationship between Sex and Power}

DOI: 10.18318/td.2017.en.2.9

The hungry Greeks... rummage underneath the rails. One of them finds some pieces of mildewed bread, another a few half-rotten sardines. They eat.

Schweiendreck, spits a young tall guard with corncoloured hair and dreamy blue eyes. ${ }^{1}$

Tadeusz Borowski

Those, who will be beautiful, will also be wise - the beautiful, wise and powerful will embody the ideal of perfection. Evil, ugliness and stupidity will disappear off the face of the earth.

Will this not entail suffering and the most elaborate cruelty? Does the end justify the means? But of course, of course. ${ }^{2}$

Stanisław Grochowiak

1.

The aim of this article is to present the alliance of sex and power by looking at the phenomenon of "sexy Fascism." The notion was derived from Susan Sontag's "Fascinating Fascism." In her essay, the American philosopher and

1 Tadeusz Borowski, This Way for the Gas, Ladies and Gentlemen, trans. Barbara Vedder (New York: Penguin Books, 1976), 34.

2 Stanisław Grochowiak, Trismus, Prozy, ed. Jacek Łukasiewicz (Warszawa: Atena, 1996), 190-191. If not otherwise specified all translations of referenced works are provided by the translator of the article.
Jakub Rawski -

Associate Professor

of Literature at

the State Higher

Vocational School in

Głogów. His research

interests encompass:

Polish emigration

Romanticism,

vampirism in

popular culture,

literature of war and

occupation, and

broadly conceived

manifestations

of difference in

2oth- and 21st-

century literature.

He published in

monographs and in

periodicals, such as

Teksty Drugie and

Prace Literackie.

Co-editor of Słowacki

i wiek XIX [Słowacki

and the Nineteenth

Century], vol. 2 (2016).

Contact: jakub-

rawski@wp.pl 
cultural theorist analyzes Leni Riefenstahl's ${ }^{\mathbf{3}}$ World War II propaganda films and writes that "fascist aesthetics... flow from (and justify) a preoccupation with situations of control," 4 in other words, power exercised over the individual and the masses. Sonntag points also to the ideal of beauty promoted by Fascism: "Fascist art displays a utopian aesthetics - that of physical perfection. Painters and sculptors under the Nazis often depicted the nude... hav[ing] the perfection of a fantasy." 5 The Nazi ideal of beauty was related to the erotic sphere: "Nazi art is both prurient and idealizing. A utopian aesthetics (identity as a biological given) implies an ideal eroticism." ${ }^{6}$ The Third Reich drew from ancient Greco-Roman standards of beauty and the remains of classical sculptures determined its directions. ${ }^{7}$ There is a notable a dichotomy in the approach to the corporeal in Nazi Germany: on the one hand, art and propaganda was teeming with sexual tension, ${ }^{\mathbf{8}}$ which still colors contemporary popular culture, ${ }^{9}$ but on the other, there is a conviction that sexuality should

3 Leni Riefenshal, artist most faithful to Nazi regime, can be seen as the creator of the clearly masculine and homosocial Nazi myth of beauty. The 2oth- and 21st-century popular culture refers, mostly unconsciously, to the image of a perfect, Aryan body visualized by the director of Triumph of the Will (1935) captures the Fascist corporeality, where "in that celebration transforming technique to myth, the camera's icy gaze reveals an obscene female fascination, tongues gliding loathsome lips, disgusting military masculinity of Hitlejugend youths patting their naked torsos," Chiara Magris, Ciocia Leni [Aunt Leni] here based on the Polish translation by Joanna Ugniewska, Zeszyty Literackie 4 (2010): 71. Susan Sontag, "Fascinating Fascism," Under the Sign of Saturn (New York: Vintage Books, 1981), 91.

5 Ibid., 92.

6 Ibid., 93.

7 See Johann Chapoutot, Fascisme, nazisme et régimes autoritaires en Europe (1918-1945) [Fascism, Nazism and the Authoritarian Regimes in Western Europe (1919-1945)], here based on the Polish translation by Andrzej Purchla, Wiek dyktatur. Faszyzm reżimy autorytarne w Europie Zachodniej (1919-1945) (Warszawa: Oficyna Naukowa, 2012), 187.

8 Apart from Leni Riefenstahl's films, one could also mention several sculptures by Arno Breker promoting the image of a perfect male Aryan body, like The Victor (1939). Works of Nazi art were and still are subject to perceptual erotization (see Sontag), even though "the National Socialist ideal of beauty in the service of »racial hygiene « meant to make the audience adopt an ideological and not aesthetic perspective." Stefan Maiwald, Gerd Mischler, Seksualność w cieniu swastyki. Świat intymny człowieka w polityce Trzeciej Rzeszy [Sexualitat unter dem Hakenkreuz: Manipulation und Vernichtung der Intimsphare im NS-Staat], trans. Ryszard Wojnakowski (Warszawa: Trio, 2003), 78.

9 Foucault asks: "How is it that Nazism, whose representatives were pitiful, pathetic, puritanical figures, Victorian spinsters with (at best) secret vices, how is it that it can have 
not be a source of pleasure, but serve reproductive, pragmatic, and political functions ${ }^{10}$ (e.g. the Lebensborn policy).

It may be worthwhile to juxtapose Sontag's hypotheses with Michel Foucault's argument about power: the French philosopher took note of the crisis of beauty (the latter usually connected to the erotic and the sphere of subjective or objective ideals). According to Foucault, beauty expresses valorization, it is one man's tool of refinement used to dominate over another. Sex is in a fundamental way linked to power and it is a negative relation." Power lays down the rule and dictates its law to sex. ${ }^{12}$ This is illustrated by the figure of the "beautiful SS-man," found incultural texts and historical sources.

\section{2.}

Jerzy Kosiński's well-known novel, The Painted Bird (1965), is narrated by a young Jewish boy in hiding as World War II rages across Europe. As the events of the narrative unfold, he encounters an SS officer. This is how the narrator tells the story of the encounter.

The instant I saw him I could not tear my gaze from him. His entire person seemed to have something utterly superhuman about it. Against the background of bland colors he projected an unfadable blackness. In a world of men with harrowed faces, with smashed eyes, bloody, bruised and disfigured limbs, among the fetid, broken human bodies, he seemed an example of neat perfection that could not be sullied: the smooth, polished skin of his face, the bright golden hair showing under his peaked cap, his pure metal eyes. Every movement of his body seemed propelled by some tremendous internal force. The granite sound of his language was ideally suited to order the death of inferior, forlorn creatures. ${ }^{13}$

The polarization noted by the protagonist is clear. Against the background of broken, bloodied bodies of the murdered, the beautiful Aryan SS-man is

become... in all pornographic literature the world over, the absolute reference of eroticism?" Michael Foucault, "Anti-rétro" Cahiers du Cinéma 5-17 (1974): 10.

10 Foucault, "Anti-rétro," 7.

11 See Michael Foucault, Historia seksualności, Vol I: Wola wiedzy [The History of Sexuality Volume 1, The Will to Knowledge], trans. Bogdan Banasiak, Krzysztof Matuszewski (Warszawa: Czytelnik, 1995), 76.

12 Foucault, Historia seksualności, 76.

13 Jerzy Kosiński, The Painted Bird (New York: Grove Press, 1976), Kindle edition. 
visualized as an angel descending on the hell of annihilation. The narrator is completely oblivious to the fact that the officer represents and is symbolically responsible for the world of those who repel him, the victims of the Nazi system. In the completely ruined world, physical beauty wins against the ugliness of the everyday. It is much easier to consume and experience beauty, sanctioned by human perception, and more readily accepted.

The boy's growing fascination and admiration for the officer's look are accompanied by desire. All of this takes place within a structure of power positioning those who wield it and those who submit to it. The narrator comments: "In the presence of his resplendent being, armed in all the symbols of might and majesty, I was genuinely ashamed of my appearance."14 He then adds: "I had nothing against his killing me. I gazed at the ornate clasp of his officer's belt that was exactly at the level of my eyes, and awaited his decision."15 His gaze directed at the crotch and the thought of death echo Sontag's remarks: "sexuality remains one of the demonic forces in human consciousness - pushing us at intervals close to taboo and dangerous desires, which range from the impulse to commit sudden arbitrary violence upon another person to the voluptuous yearning for extinction of one's consciousness, for death itself."16 The narrator continues: "I knew my fate was being decided in some manner, but it was a matter of indifference to me. I placed infinite confidence in the decision of the man facing me. I knew that he possessed powers unattainable by ordinary people."17 The protagonist's idealization of the SS-man also implies trust. Maria Janion states clearly: "in The Painted Bird, the child falls in love with the beautiful blonde beast, the fair angel in the uniform of a high-ranking SS officer."18

To sum up, the relation between the oppressor and the victim described by Jerzy Kosinski is a good example of how fascination with the physicality of the former evokes subsequent emotions and experiences, such as the already mentioned trust or a death wish of erotic nature.

The eponymous protagonist of Ignacy Karpowicz's Sońka similarly succumbs to the irresistible, radiating beauty of the Nazi persecutor. Written five decades after The Painted Bird, the novel presents a similar, although more complexly narrated, honest and naive fascination with the SS oppressor.

14 Ibid.

15 Ibid.

16 Susan Sontag, "Pornograpic Imagination," in Styles of Radical Will (London: Penguin Modern Classics, 2009), 57. 
It is World War II and the Nazis enter a small Podlachian village; the female narrator describes them as fascinating creatures: "with beautiful, chiseled faces, rosy-golden skin and hair like frames for icons... athletic bodies. They looked beautiful, dangerous and noble,"19 and among them is SS officer Joachim Castorp with a "sickeningly" telling name $(S, 119)$ and "the bluest, most piercing and merriest eyes, large and bright" $(S, 32)$ whom Sońka falls for. He wears, of course, the emblematic black uniform $(S, 46)$ with "two steel SS bolts," and Sońka compares sex with him with "a ball of lightning exploding in her brain." $(S, 46)$

Sonia's attitude eludes clear moral categories, resulting from an impossible, forbidden love and we know that "whatever is done from love always occurs beyond good and evil."20 Her state means that Sońka's perception of the war (symbolized by Joachim), is entirely different from everyone else's. Ryszard Koziołek notes: "Karpowicz... tells their tale against history."21 The protagonist confesses: "I prayed fervently... for the Germans to win and stay here forever" $(S, 47)$. Recalling the occupation years later, she exclaims: "How I miss the war! Why did it have to end?" $(S, 67)$

When the Germans start killing the villagers, Sonia never stops to idealize Joachim, quite on the contrary: "My poor, fair Joachim, his beautiful body, suddenly delineated by the twisted silhouettes of corpses." (S, 61) Although she is aware of the murderous acts of her beloved, the protagonist still retains feelings for him, committing a serious transgression, sentencing herself to banishment - social exclusion: "They saved the harshest punishment for Sonia... turn[ing] their eyes away from her." $(S, 174)$

War becomes a synonym for Joachim and the whole social-historical context becomes largely insignificant because "Sonia could not conceive Joachim as a German. Germans were the ones who did the shooting, burned down villages, confiscated food and livestock" $(S, 83)$. It seems that Koziołek is wrong in his claim that "the loving Sońka implements, honestly and fervently, the policy of reconciliation."22 The protagonist is not interested in such issues. Rather, she is completely taken over by the emotion which fills her entire existence - historiosophical reflections are absent from her notion of war (which is not to imply that she is incapable of such reflections). The feeling that connects the Pole and the German does not flow from the policy of

19 Ignacy Karpowicz, Sońka (Kraków: Wydawnictwo Literackie, 2014), 30. The following citations are marked in the text as ( $S$, page number).

20 Friedrich Nietzsche, Beyond Good \& Evil: Prelude to a Philosophy of the Future, trans. Walter Kaufmann (New York: Vintage Books, 1989), 90. Ryszard Koziołek, "Esesman, mój bliźni," ["My neighbor, SS-man"] Ksiq̨żki 2 (2014): 11. Ibid., 11. 
reconciliation also in the metaphorical dimension, it is located outside the historical context, focused only on itself, on the "here" and "now." Their love is obsessive, honest and unconditional - as in Stanisław Grochowiak's poem "Invitation to Love" where the speaker "invites" the addressee of the poem to love regardless of her age and looks. ${ }^{23}$

Joachim is "fair" $(S, 92)$, holy $(S, 93)$, "radiant" $(S, 110)$, infinitely idealized: "He was the iris of my eye. The navel of my world. The tongue of my mouth. The fingerprint of each fingertip. The outline of my womanhood. My incandescent Joachim" $(S, 99)$; "My Joachim... the aureole of my saints... My golden Joachim" $(S, 137)$. Many of Sonia's descriptions have religious connotations to holiness and light, that is, to the sphere of the sacred that is distinctly ideal and positive. The protagonist is fully under the Nazi's thrall - one not based on force or violence, but on beauty.

\section{3.}

Also the cinema provides examples of beautiful, Nazi soldiers-tormentors embodying both beauty and power. Analyzing the essays by the Russian writer Slava Mogutin, Grzegorz Ojcewicz notes that "cinematic art significantly influenced and continues to influence the sexual image of fascism," 24 not to mention The Night Porter (1974) where fascism is sexualized in the figure of an SS-man. The film tells the story of Max, a former SS officer and his relation to Lucia, whom he meets after the war and who was his sexually abused victim in the concentration camp in Dachau. ${ }^{25}$ They renew their sadomasochistic relation in a Hegelian master-slave dialectic, ${ }^{\mathbf{2 6}}$ as in the poem by the Nobel prize winner, Nelly Sachs:

Footsteps -

The primeval game of hangman and victim,

bully and bullied,

hunter and hunted -

23 "Gaunt - catty / Clumsy - now fat / Wearing a wig / Angered / Spectacled // I am coming to you through my rotten dreams / In the iron shoes. Stanisław Grochowiak, Zaproszenie do miłości [Invitation to Love], in Poezje wybrane (Warszawa: PIW, 2001), 179.

Grzegorz Ojcewicz, Skazani na trwanie. Odmieńcy XX wieku w esejach Jarosława Mogutina (Olsztyn: Portret, 2007). 


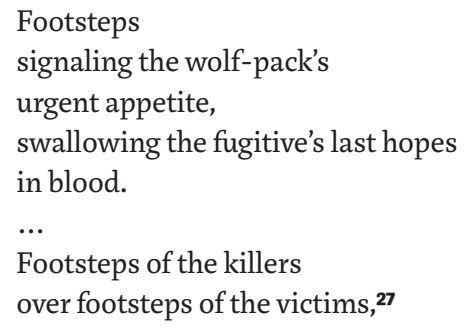

The trauma of the past leads to a repetition of the relation, and bondage created during the war retains its hold. The characters of The Night Porter decide to recreate the old relationship and initiate a certain theatrical performance where they play the main parts. ${ }^{\mathbf{2 8}}$ Michel Foucault asserts that pleasure and power are not mutually exclusive but reinforce one another. ${ }^{29}$ The protagonists of The Night Porter inhabit the "gray zone" (to quote Primo Levi)

in which the "long chain of conjunction between the victim and executioner" comes loose, where the oppressed becomes oppressor and the executioner in turn appears as victim. A gray, incessant alchemy in which good and evil, along with them, all the metals of traditional ethics reach their point of fusion. ${ }^{30}$

An alternative vision of World War II can be found in Quentin Tarantino's Inglorious Basterds (2009), including the figure of a Nazi who tries to use his power over an individual belonging to occupied French society: private Frederick Zoller (Daniel Brühl) is convinced that no woman can resist his beauty and glory of having murdered three hundred Allied soldiers. He meets a beautiful cinema owner, Emmanuelle Mimieux (Mélanie Laurent) whom he tries to woo and who remains immune to those attempts. What

27 Nelly Sachs, "That the persecuted should not become persecutors" (Auf daß die Verfolgten nicht Verfolger werden) from Sternverdunkelung (1949), trans. Andrew Shanks, $<$ http://www.nellysachs-translations.org.uk/stern.html\#footsteps>, accessed December 28, 2017 .

28 See Katarzyna Przyłuska-Urbanowicz, Pupilla (Gdańsk: słowo/obraz terytoria 2014), 185-226.

29 Foucault, Historia seksualności, 50.

30 Giorgio Agamben, Remnants of Auschwitz: The Witness and the Archive, trans. Daniel Heller-Roazen (New York: Zone Books, 2008), 21 
Zoller does not know is that Emmanuelle is Jewish, her real name being Shoshanna Dreyfus, and that she was the only one to survive the massacre of her family.

When he finally manages to meet her alone, Emmanuelle draws a gun and shoots him. The audience is shown the face of the woman, overcome with a kind sorrow, a certain sadness resulting from her act. She leans over Zoller, probably to stroke his head, but before she does so, he also reaches for his gun and murders Emmanuelle. Both die. ${ }^{31}$ The coloring of the scene is not to be ignored. Zoller is dressed in a white uniform (white being the symbol of innocence - here his innocent intentions), Mimieux wears a red dress (symbolizing extreme emotions: anger, fury, and love). It is interesting that instead of regaining peace after she shoots the Nazi, the victim of the Nazi system experiences opposite emotions. Let us compare Tarantino's scene with Zbigniew Herbert's "Achilles. Penthesilea" where the Achaean warrior, upon mortally wounding the Amazon, falls in love with her.

When Achilles with his short sword pierced the breast of Penthesilea ... he noticed that the queen of the Amazons was lovely. He laid her carefully on the sand, took off her heavy helmet, unclasped her hair, and gently arranged her hands on her bosom. He lacked, however, the courage to shut her eyes. He gave her one more, last, farewell look, and, as though suddenly overpowered by an outer force, cried. ${ }^{32}$

A similar phenomenon takes place in the scene from Inglorious Basterds: the "outer force" gives birth to a transgressive feeling whose signs manifest themselves on Emmanuelle's face, emphasized by the attempt at a tender gesture which turns out to be impossible as Eros and Thanatos become joined in a (im) mortal embrace, not for the first time and not the last in the history of culture. There is only a shift in the aspect of sex, a change of genders - Mimieux becomes Achilles and Zoller plays the part of Penthesilea.

In her discussion of Inglorious Basterds, Kazimiera Szczuka points to the "sexy Fascism" of Hugo Stiglitz (Til Schweiger) whom he describes as follows: "A dark, devastatingly handsome Wehrmacht officer... is

31 Inglorious Basterds (Germany and USA, 2009), dir. Quentin Tarantino.

32 Zbigniew Herbert, "Achilles. Penthesilea," trans. Joseph Brodsky, The New York Review of Books (October 21, 1993) < http://www.nybooks.com/articles/1993/10/21/achilles-penthesilea/>, accessed November 28, 2017. 
a phenomenal embodiment of the mass audience's hidden desires." 33 But one should not forget about the ethical context: by producing images of handsome SS men, popular cinema desensitizes audiences to fascism. Murderous ideology whose political and economic implementation cost the lives of millions, at the turn of the 21st century, becomes associated with the image of an attractive, seductive man dressed in a well-tailored black uniform. ${ }^{34}$ Stanisław Buryła refers to this growing phenomenon as the "aesthetization of the tormentor" ${ }^{35}$ which should be placed in the context of "mass culture's domestication of the Holocaust, which is its narrative totalization," notes Jerzy Topolski. ${ }^{36}$

4.

Yuri Lotman and Zara Mints argue that mass culture, with its tendency for simplified generalizations, is an especially fertile ground for the creation of myth. ${ }^{37}$ The popular myth of the beautiful SS-man born in second half of the 2oth century, may be illustrated, for instance, by a 2012 Polish campaign to commemorate the International Holocaust Remembrance Day on 27th January. The poster presents a self-confident, young, handsome model wearing the SS-Obersturmführer uniform with the caption: "My name is Hans. I'm 25 years old. In December 1943, I killed 40 people in Warsaw's Wola district. Remember me so that the history does not repeat itself." ${ }^{38}$ The author of the initiative, Wojciech Jeżowski, explains his idea as follows:

33 Kazimiera Szczuka, "Łowca niedźwiedzi," Krytyka polityczna 22 (2010): 125.

34 Slava Mogutin writes: "The Nazi uniform ... seems to have been created not for the war but for festivities and sexual amusement. It is too beautiful and theatrical, almost indecent and pornographic," Slava Mogutin ексуальность фашизма, http://mitin.com/ people/mogutin/fashism.shtml, accessed August 17, 2014, cited in Ojcewicz, Skazani na trwanie, 225.

Stanisław Buryła, Tematy (nie)opisane (Kraków: Universitas, 2013), 404-416.

36 Jerzy Topolski, Jak się pisze i rozumie historię. Tajemnice narracji historycznej (Poznań: Wydawnictwo Poznańskie, 2008), 328.

37 Yuri Lotman, Zara Mints, "Literatura i mitologia" ["Literature and mythology"] in Sztuka wświecie znaków, trans. Bogusław Żyłko (Gdańsk: słowo/obraz terytoria, 2002), 81.

38 The poster even had a Facebook fanpage, "Pamiętaj o mnie, by to się nigdy nie powtórzyło" https://www.facebook.com/pages/Pamiętaj-o-mnie-by-to-się-nigdy-nie-powtórzyło/315851678467500, accessed July 11, 2014. 
The world of today's youth revolves around parties and shopping malls. There is less and less time to reflect. Young people remember things that shock them and raise controversy. I knew that a young, handsome man in an SS-uniform will make the poster very expressive. What matters the most to me is the fact that the issue of the Holocaust is discussed, as well as the awareness that evil may lurk in each and every person. ${ }^{39}$

But the man seductively looking down from the poster not only exemplifies the aesthetization of Fascism but, above all, diverts the audience's attention from the idea that it was meant to convey. What is at the center of the work is not the memory of the victims but of their tormentors and those behind the Nazi genocide. The actual message is encrypted, covered by the sexual object seducing the viewers with its power, crime, gaze and, most of all, appearance. It encourages, even provokes homo- and heterosexual fantasies. The explanation provided by the author ("evil may lurk in each and every person") seems rather trite and does not require a sexy Fascist to be proven. One needs to look no further than the Stanford Prison Experiment to find manifestations of the dark side of the human psyche.40 The discussed poster received a "Chamlet," a mock award in recognition for the worse advertisement of the year.41 This part of my argument is well summed up by a passage from Susan Sontag's essay:

After Marcin Świejkowski, "Jacy piękni ci naziści!" http://www.kampaniespoleczne.pl/ kontrowersje,4110,jacy_piekni_ci_nazisci, accessed December 2, 2012.

40 See also Philip Zimbardo, The Lucifer Effect: Understanding How Good People Turn Evil (New York: Random House, 2007).

One of the jurors, Professor Dariusz Doliński, explains: "This Chamlet was awarded for the discrepancy between the image and the message. The authors' intention seemed clear: don't be fooled by appearances, this neat looking, nice boy is a murderer. But the poster takes an entire newspaper page which the viewers look at for less than a second. This is too short to decipher the message." Cited after Małgorzata Porada-Labuda "Chamlety przyznane, nieodebrane," <http://www.uni.wroc.pl/wiadomo\% $\mathrm{C}_{5} \% 9 \mathrm{Bci} /$ konkursy/ chamlety-przyznane-nieodebrane>, accessed December 2, 2012. Professor Jerzy Jastrzębski adds: "The statue of Chamlet, a crumpled piece of paper, was awarded to the authors of the campaign for the lack of brain and the love of for Leni Riefenstahl whose poetic they represent. I was also under the impression that the gentleman presented on the poster sends an erotic, sado-masochistic signal: 'I killed 40 people, kill me'," cited in Lucyna Róg, "Faszyzm łagodzą seksizmem," Gazeta Wyborcza Wrocław (24 November 2012), 2, supplement to Gazeta Wyborcza 275 (2012). 
Art which evokes the themes of fascist aesthetic is popular now, and for most people it is probably no more than a variant of camp. Fascism may be merely fashionable... The hard truth is that what may be acceptable in elite culture may not be acceptable in mass culture, that tastes which pose only innocuous ethical issues as the property of a minority become corrupting when they become more established. ${ }^{42}$

\section{5.}

Increasingly reproduced by mass culture, the image of the beautiful Nazi can be found also in the German miniseries, Generation War, personified by the main protagonist, Wehrmacht lieutenant Wilhelm Winter (played by Volker Bruch). Although not a member of the formation where the sexy Fascists typically come from - Winter is in the army and not the SS - he embodies the myth of the beautiful Nazi with regard to appearance: he is young and handsome, noble, loyal to the fatherland, he has a code of honor and is platonically in love with a nurse called Charlotte. Even when he executes a Soviet prisoner, ${ }^{43}$ the audience receives a very clear message that Wilhelm is following orders which he cannot (and should not) ignore, being meticulous and conscientious. Commenting on the Eichmann's trial, Leszek Kołakowski wrote: "No one in the world is excused on the ground of following an order or fulfilling the soldier's duty." 44

An unsettling cognitive dissonance appears in the sphere of ethics when the viewer realizes the whitewashing and justifications for the Nazi murders veiled by the figure of the beautiful Nazi. Wilhelm's ideal image is completed by the scenes of his later defection, the threat of death penalty, assignment to a penal battalion and lonely exile in the Soviet Union and Poland. ${ }^{45}$ This means that Wilhelm's sins are entirely erased (on the surface, of course) and he holds the imagination of the viewers, mass audiences, enthralled, gaining their favor both through his looks and his tragic biography.

42 Sontag, "Fascinating Fascism," 98.

43 Generation War: Our Mothers, Our Fathers, ep. I: "A Different Time" (Germany, 2013), dir. Philipp Kadelbach. Leszek Kołakowski, "Casus Eichmanna," Gazeta Wyborcza 166 (2014): 27. 


\section{6.}

Jan Karski, the legendary Polish emissary and courier, who in 1943 revealed in the United States the truth about the Holocaust, was arrested by the Gestapo in 1940 . He describes the figure of the SS officer who questioned him as:

an extremely handsome young man. About the age of twenty-five. He was tall, lean, had blonde hair and blue eyes...He looked like a Prussian Junker. When he energetically strode across the room, I looked at him with a certain sense of fascination. ${ }^{46}$

The SS-man tells the prisoner about his youth. Karski comments: "He was a delicate boy, interested in the arts, but his father wanted to raise a true officer." ${ }^{47}$ At some point in the conversation, the German says:

I don't know if you realize but NSDAP is founded on typically male ideals. Our entire ideology is masculine ... during my school years in Ordensburg I never talked to girls voluntarily, unless it was a part of my duties. I believed that honest conversations can only concern men. ${ }^{48}$

What is revealed here is the homoerotic character of Nazism. The German school which groomed the future SS- $\operatorname{man}^{49}$ constitutes a clearly masculine sphere, separated from the feminine. The right-winged, anti-humanist and totalitarian ideology became the crowning piece or even a monstrous apogee of patriarchy. ${ }^{50}$ The woman was seen only in reproductive categories, as

46 Jan Karski, Tajne państwo. Opowieść o polskim podziemiu, ed. Waldemar Piasecki (Warszawa: Rosner \& Wspólnicy, 2004), 137.

47 Ibid., 138.

48 Ibid., 138.

49 Attempts to locate the roots of the German Nazism can be found in Michael Haneke's 2009 The White Ribbon (Austria, France, Germany, Italy).

The German Conservative Revolution attributed, for instance, the male-male relations with statehood-creating potential as well as a monopoly for all positive and constructive action. Women were to be excluded from the sphere of these relations and completely subordinated - Elżbieta Janicka, Sztuka czy naród? Monografia pisarska Andrzeja Trzebińskiego (Kraków: Universitas, 2006), 220 footnote 36. "The theory of the male society (Männerbundtheorie) was created by Hans Blüher who formulated the thesis of two erotic drives. The first one was directed at women and founded the family. The second one allowed men create communities which opposed the world of family life, such as army, political societies, state. Both his theory and the practice of youth bunds included homosexual elements even though the author of Die Rolle der Erotikin der Männlichen Ge- 
a future mother of ideal Aryans, a kind of incubator for the "master race"; the national-socialist worldview had no room for independent, sexually active women. ${ }^{\mathbf{5 1}}$ Hitler writes in Mein Kampf:

The People's State will have to direct the education of girls just as that of boys and according to the same fundamental principles. Here again special importance must be given to physical training and only after that must the importance of spiritual and mental training be taken into account. In the education of the girl the final goal always to be kept in mind is that she's one day to be a mother. ${ }^{52}$

Only the man is perceived as fully human - an Aryan man, naturally, embodying the notion of the beautiful and ideal Fascist, which in turn shaped the art of the Third Reich since, as Umberto Eco notes, Nazi mysticism and its homosexual consequences domesticated the anatomical truth following the ideological requirements. ${ }^{53}$

Homoeroticism stayed hidden behind the state's homophobia, ${ }^{54}$ programmatic for Nazi ideology and its legal instantiations (i.e. persecution, arrests, death penalty sentences, concentration camps)..$^{55}$ The fear of homosexuality is frequently attributed to repressed homosexual desire. ${ }^{56}$ The Nazi system was based on the military; SS-units were a paramilitary formation which included also fully militarized units of Waffen-SS. Slavoj Žižek notes that "homosexual libidinal economy bears witness to the fact that the discourse of the military

sellschaft probably had in mind some kind of its sublimated version, enabling the creation of the specific relationship in question." Wojciech Kunicki, "Wprowadzenie," in Rewolucja Konserwatywna w Niemczech 1918-1933, ed. Wojciech Kunicki (Poznań: Wydawnictwo Poznańskie, 1999), 74-75, quoted after Janicka, Sztuka czy naród?, 220, footnote 36.

Maiwald, Mischler, Seksualność w cieniu swastyki, 7 and 93-97.

52 Adolf Hitler, Mein Kampf, trans. James Murphy (London and New York: Hurst and Blackett Ltd., 1942) 322.

53 Umberto Eco, Po drugiej stronie lustra i inne eseje. Znak, reprezentacja, iluzja, obraz, trans. Joanna Wajs (Warszawa: W.A.B., 2012), 75.

54 Reich Office for Combating of Homosexuality and Abortion was founded in 1937; later the Reich Security Headquarters (RSHA) included Reich Offices for Combating Homosexuality, Drug Offences, International White Slave Trade.

55 Maiwald, Mischler, Seksualność w cieniu swastyki, 139-161.

56 Katarzyna Bojarska-Nowaczyk, "»Przegięte ciotki niemile widziane«- o homofobii wśród gejów i lesbijek," Parametry pożądania. Kultura odmieńców wobec homofobii, ed. Tomasz Basiuk et al. (Kraków: Universitas: 2006), 61-72. 
community can only operate by censoring its own libidinal foundation."57 Importantly, one of the more prominent Nazi activists and SA leader Ernst Röhm who did not hide his homosexuality was murdered partly for that reason. ${ }^{58}$ The subject seems to attract artists: Polish films such as Deborah ${ }^{\mathbf{5 9}}$ and Kormblumenblau ${ }^{\mathbf{6 0}}$ feature the figure of a Nazi homosexual; ${ }^{\mathbf{1 1}}$ Pasażerka tells the story of a female SS-officer platonically fascinated with a female prisoner in Auschwitz-Birkenau. ${ }^{62}$

\section{7.}

The phenomenon of sexy Fascism is represented best by SS-Hauptsturmführer Dr. Josef Mengele, a Nazi murderer who conducted pseudo-medical experiments on Auschwitz prisoners and wielded unlimited power over their life and death. The accounts of female prisoners and his victims suggest that he was often perceived as a handsome, interesting man, despite his deadly activities, and was referred to, among others, as "the beautiful Satan."63 The abjectivity of that expression ${ }^{64}$ outlines the frame of ambivalence encountered by Mengele's victims - there is a reason why Sławomir Buryła calls this type of criminal a "greater intellectual challenge."65

Hanna Krall recalls the story of a Polish nurse who, attempting to save her life, approached Josef Mengele on a ramp in Auschwitz. The narrative

57 Slavoj Žižek, The Plagues of Fantasies (London and New York, Verso: 1997), 25.

58 Karol Grünberg, Adolf Hitler. Biografa Führera (Warszawa: Książka i Wiedza, 1988), 133-134; see also Karol Grünberg, SS - gwardia Hitlera (Warszawa: Książka i Wiedza, 1994), 47; Maiwald, Mischler, Seksualność w cieniu swastyki, 38-45; Slavoj Žižek Rewolucja u bram. Pisma Lenina z roku 1917 [Revolution at the Gates: Žižek on Lenin: The 1917 Writings], trans. Julian Kutyła (Kraków: Wydawnictwo Krytyki Politycznej, 2007), 440.

Deborah (Poland, 1995), dir. Ryszard Brylski.

60 Kornblumenblau (Poland, 1998), dir. Leszek Wosiewicz.

61 More in Sebastian Jagielski, Maskarady męskości. Pragnienie homospołeczne w polskim kinie fabularnym (Kraków: Universitas, 2013), 379-403.

62 Pasażerka (Poland, 1963), dir. Andrzej Munk.

63 Ulrich Völklein Josef Mengele. Doktor z Auschwitz, trans. Artur Kuć, Urszula Poprawska (Warszawa: Prószyński i S-ka, 2011), 9.

64 Julia Kristeva, Powers of Horror: An Essay on Abjection (New York: Columbia University Press, 1982).

65 Buryła, Tematy (nie)opisane, 272. 
includes the following statement: "Doctor Mengele - handsome, polite."66 Lidia Ostaszewska's Farby wodne [Water Paints], a volume of reportages about Dina Babbit (née Gottliebová), Jewish painter who worked for Mengele in Auschwitz so that her life was spared, recalls the artist's description of the criminal: "He had a rather nice, distinct face, with mouth shaped like the letter M... a mane of hair. But his eyes were dead... swarthy, dark-eyed, dark-haired. One of the women in our camp said he was handsome. He was indeed, but he was also an SS-man."67

Gerald L. Posner and John Ware write: "The memory of this slightly built man, scarcely a hair out of place, his dark green tunic neatly pressed, his face well scrubbed, his Death's Head SS cap tilted rakishly to one side, remains vivid for those who survived his scrutiny when they arrived at the Auschwitz railhead."68 And later:

Many have testified to his immaculate and well-manicured appearance as he exercised his power of life and death. Some women, whom he was not adverse to humiliating by having them parade naked while he carried out his selections, found him a handsome man... Survivors remarked on the impression made by his tight-fitting SS uniform with glistening black boots, white glove and polished cane as he surveyed his prey with a sure eye, smiling sometimes. ${ }^{69}$

Ernst Klee observes: "Mengele's descriptions differ from the way he is usually imagined... He attached great importance to a clean appearance, and even had a prisoner-masseur."70 Doctor Mancy Schwalbe recalls that "he created the impression of an elegant, beautiful man with exquisite manners."71 Janina Gołębiowska, a camp prisoner, describes him as "proportionally built, with an charming face."72 Doctor-prisoner, Ella Lingens claims "he was a strikingly

66 Hanna Krall, Hipnoza (Kraków: a5, 2002), 26.

67 Lidia Ostałowska, Farby wodne (Wołowiec: Czarne, 2011), 72.

68 Gerald L. Posner, Michael Berenbaum, John Ware, Mengele: The Complete Story (New York: Cooper Square Press, 1986), 2.

69 Ibid., 27.

70 Ernst Klee, Auschwitz. Medycyna III Rzeszy i jej ofary [Auschwitz: Nazi Medicine and its Victims], here based on the Polish translation. E. Kalinowska-Styczeń (Kraków: Universitas, 2011), 440 .

71 Ibid., 441.

72 Ibid., 441. 
beautiful and elegant man."73 Also the Slovakian doctor-prisoner Margita Schwablova mentions "an elegant and handsome man with great manners."74 Solti Dezso from Hungary remembers Mengele as "very handsome. He was extremely well-groomed... he had very thick, dark hair. I recall his eyes, very bright. He really didn't look like a murderer."75

Aniot śmierci [Angel of Death], a 2008 documentary, includes reports by female prisoners who survived Mengele's experiments: "He was an incredibly handsome and elegant man"76 (Wanda Marossanyi); "Handsome young man, very polite"77 (Ruth Elias). When Mengele arrived in Auschwitz in May 1943, prisoner Anna Palarczyk says "we found out that there was a new doctor, that he was handsome - And I also heard that he was evil."78

Opinions on the appearance of the Nazi criminal cited above show the degree to which human sexuality determines perception. The victims did not see Mengele (initially) as a murderer but as a handsome man. His limitless power in the concentration camp was also an important factor. Foucault argues that the relations of power to sex and pleasure branch out, multiply, measure the body and penetrate modes of conduct. ${ }^{79}$ The Nazi criminal, despite the dictates of ethics, becomes an object of desire, his perfectly tailored SS uniform only enhances the impression, magnifying his sexual aura.

The reports of female prisoners illustrate the phenomenon of coding sexuality.80 In the ethical paradigm, Mengele is synonymous with evil, death, crime, suffering, and indeed, he is commonly perceived as such. But when an average consumer of media and culture, born after World War II, encounters the reports of the victims who compliment the physical appearance of their tormentor, a cognitive dissonance results: expected opposition (handsome man vs Nazi criminal) is missing, because Mengele is precisely a handsome Nazi criminal. The figure of the cruel SS-man inspired numerous

\footnotetext{
73 lbid., 441.

74 Völklein, JosefMengele, 23.

75 Ibid., 131.

76 Aniołśmierci (Poland, 2008), dir. Marta Minorowicz-McBride.

77 Ibid.

78 Ibid.

79 Foucault, Historia seksualności, 50.

80 More in Ferdinand Fellman, "Miłość i seksualność w ludzkim samorozumieniu," trans. Andrzej Przyłębski, Fenomenologia 8 (2010): 31-39.
} 
filmmakers: Mengele was played by Gregory Peck in The Boys from Brazil, ${ }^{\mathbf{1 1}}$ he appears also in The Grey Zone ${ }^{\mathbf{8 2}}$ and Out of the Ashes, ${ }^{\mathbf{8}}$ in The Unborn (a horror movie) one of the characters recalls a doctor from Auschwitz who was "very handsome" and "obsessed with twins" 84 (Mengele's pseudo-medical research focused mostly on twins and people with dwarfism); the German Doctor (2013) tells the story of a family that in the 196os shared the house with Mengele who continued to elude capture. ${ }^{85}$

Desire escapes the laws of logic, following the law of nature and physiology. It often evades expectations and accepted social norms, especially female desire, marginalized in patriarchal culture. Desire becomes a language used by women to accentuate their subjectivity; to use Julia Kristeva's terminology, it is semiotic. ${ }^{86}$ Consequently, in this case, sexuality becomes ambivalent, coded, hidden, pushed to the sphere of fantasy, thoughts and, with time, unwanted memory. Women who met Mengele in Auschwitz-Birkenau and survived his pseudo-medical experiments were only research objects to him; their position in the concentration camp was subordinate (as victims, slaves, research objects) ${ }^{87}$ Elfriede Jelinek writes that "the woman as such has no

81 The Boys from Brazil (USA and Great Britain, 1978), dir. Franklin James Schaffner. Discussed in Zygmunt Kałużyński's Bankiet w domu powieszonego (Warszawa: BGW, 1993), 67-69. The movie was made while the criminal was still alive (Mengele died on 7 February 1979).

82 The Grey Zone (USA, 2001), dir. Tim Blake Nelson, based on Miklós Nyiszli's I Was Doctor Mengele's Assistant, trans. to Polish by T. Olszański, Byłem asystentem doktora Mengele. Wspomnienia lekarza z Oświęcimia (Oświęcim: Państwowe Muzeum Auschwitz-Birkenau, 2000).

83 Out of the Ashes (USA, 2003), dir. Joseph Sargent.

84 The Unborn (USA, 2009), dir. David Samuel Goyer.

85 The German Doctor (Argentina, France, Spain, Norway 2013), dir. Lucía Puenzo, based on Puenzo's Wakolda, trans. to Polish by Bernadeta Krysztofiak (Zakrzewo: Replika, 2014).

86 Julia Kristeva, La révolution du langage poétique. L'avant-garde à la fn du XIXe siècle: Lautréamont et Mallarmé (Paris: Éditions du Seuil, 1974). For a discussion of the Polish reception of the distinction between the semiotic" and "symbolic" see Joanna Bator, "Julia Kristeva - kobieta i "symboliczna rewolucja," Teksty Drugie 6 (2000): 7-26; Paweł Dybel, Zagadka "drugiej płci."Spory wokół różnicy seksualnej w psychoanalizie i w feminizmie (Kraków: Universitas, 2012) 59-61; Ewa Hyży, Kobieta, ciało, tożsamość. Teorie podmiotu w filozofii feministycznej końca XX wieku (Kraków: Universitas, 2003), 181.

87 "In concentration camps, the authorities treat the body as an object, biological material exposed to trials leading to the state of »bare existence«; it represented more than physical salvation, its state determined the entire... human fate. For the prisoner, the body was a private space (the only private space in the camp) and consequently, the prisoner attempted (unconsciously) to counteract it being reduced to its components ... The 
worth nor value, being worthless she also is not valued as a mother... concentration camps were »shredders « of human material, they squandered people, wasting that which could be used, but profit was not the goal of concentration camps."88

Mengele's female victims could have been easy prey for sexual abuse, but this never took place - the criminal's biography suggests he was a fanatical Nazi his entire life and remained faithful to the Fascist notions of master race, racial purity etc. ${ }^{89}$ As such, for ideological reasons, he could not enter into any erotic relations with a member of the non-Aryan race. Thus, we can speak of a phenomenon which could be described as sexuality without sex. To Mengele, the female body in the camp was erotically silent. Only in thought could Mengele be called "handsome" and only in this way could female desire become subversive - this was the only form of corporeal discourse in the camp: Mengele and the female prisoner. ${ }^{\mathbf{9 0}}$

The woman notices the beauty of the oppressor which entails the aesthetization of Fascism. It seems, however, that more transpires in the encounter between Dr. Mengele and the female prisoners in the biological but also in the ontological sphere, exceeding superficial aesthetization. Calling the Nazi criminal an "angel" or referring to the SS-man in Kosiński's novel as a "wonderful being" comes from a physical attraction, but also attributes the oppressor with positive traits (the halo effect). ${ }^{\mathbf{9 1}}$

practice of sexuality was among those tactics of "salvation«," Beata Karwowska, Ciało. Seksualność. Obozy zagłady (Kraków: Universitas, 2009), 160-161.

Elfriede Jelinek, "Kobieta i jej przeznaczenie. Kobiety i obozy koncentracyjne," ["The woman and her destiny. Women and the concentration camps"] Moja sztuka protestu. Eseje i przemówienia, trans. to Polish by Piotr Bikont et al., ed. Agnieszka Jezierska, Monika Szczepaniak (Warszawa: W.A.B., 2012), 312.

Zob. Posner, Berenbaum, Ware, Mengele, 263, 266-267, 305.

Literary images of sexuality, both female and male, and the body's existence in several orders (social, political, erotic) in the concentration camps are discussed in Beata Karwowska, Ciało. Seksualność. Obozyzagłady. What seems especially interesting in the context of the present article, is the subject of female prostitutes visited by the prisoners and the SS-men (described, among others, by Tadeusz Borowski in "Here in Our Auschwitz." See also Elfriede Jelinek, "Kobieta i jej przeznaczenie," 306-315; Beata Karwowska, Ciało. Seksualność. Obozy zagłady, 171-194; J. Ostrowska, "Wielkie przemilczenie. Prostytucja w obozach koncentracyjnych," Krytyka Polityczna 14( 2007): 176-192; Joanna Stöcker-Sobelman, Kobiety Holokaustu. Feministyczna perspektywa w badaniach nad Shoah. Kazus KL Auschwitz-Birkenau (Warszawa: Wydawnictwo Trio, 2012), 50-51.

91 The tendency to automatically attribute character traits basing on the positive or negative impression. 
Thus, sexy Fascism appears to be a behavioral but also a psychological issue. In "the world of stone,"92 noticing the beauty of the oppressor is not purely sexually driven; it comes from the need to give meaning to one's existence, emphasize one's humanity and subjectivity despite it being reduced to a prisoner's number.

8.

Cultural texts discussed in this article present the phenomenon of "sexy Fascism," derived from Susan Sontag's notion of "fascinating Fascism," and illustrate Michel Foucault's argument about the relation of sex and power. The ethical issue, resulting from a cognitive dissonance, appears to be the most unsettling aspect of the problem: fascism becomes aestheticized and sexualized while the criminal nature of the system is ignored or whitewashed.

Piotr Uklański's observation on the matter seems particularly insightful here: in one of the interviews, the artist behind Naziści ${ }^{93}$ comments: "Soon we will know the war only from movies, where Nazis are played by handsome blondes." ${ }^{94}$ While this is taking place in popular culture, high culture has nonetheless produced numerous texts, both cinematic ${ }^{95}$

92 Tadeusz Borowski, "The World of Stone," in This Way for the Gas, Ladies and Gentlemen (New York: Penguin, 1976).

93 A composition consisting of a series of color and black and white potraits of actors playing the roles of Nazis, created in 1998 and first exhibited in Photographer's Gallery in London.

94 "»Żaby bym nie ukrzyżował.« Z Piotrem Uklańskim rozmawia Piotr Pacewicz," Wysokie Obcasy 7 (2013), 46. Similarly, Sławomir Buryła concludes: "The Holocaust topic (as may already be seen) will be increasingly taken over by the broadly understood popular and mass culture...This may entail a fascination with the Fascist supremacy of strength and violence including the Nazi emblems, and result in kitch, empty entertainment which ignores the moral and historical contexts," Sławomir Buryła, "Topika Holokaustu. Wstępne rozpoznanie." Świat Tekstów. Rocznik Słupski 10 (2012): 151.

95 It is worth to recall for instance the broadly praised Schindler's List by Steven Spielberg (USA, 1993) where Amon Göth, commandant of the concentration camp in Płaszów, is played by Ralph Fiennes because of his "dark sexuality," Schindler's List <http://www.flmweb.pl/Lista. Schindlera/trivia> accessed September 6, 2014. In Steven Spielberg's Oscar-winning movie, the audiences see Göth using his position in the camp, the resulting power and appearance to draw into a sado-masochistic game a Jewish servant, Helena, presented solely for the sexual aspect. Bartosz Kwieciński notes that Spielberg's version of the Shoah proves "how easy cinematic imagination gives in to the erotic aspect of totalitarian terror and acknowledges the terror as a metaphor of the seductive power of Nazism, with its promise of purity and submission of the slave races," Bartosz Kwieciński, Obrazy i klisze. Między biegunami wizualnej pamięci Zagłady (Kraków: Universitas, 2012), 305. 
and literary, ${ }^{\mathbf{9 6}}$ concerned with aesthetization and erotization of Nazism. Mogutin argues that "the sexual character of Fascism was transformed from a taboo into profitable commerce. Fascism remains a show-business,"97as seems to be evidenced by Nazi exploitation movies, the pornographic variety of the exploitation genre, ${ }^{\mathbf{9 8}}$ dating back to the 1970 s when "Fascist symbols and gadgets began to turn into fetishes and found broad application in the porno business."99

The category of "sexy Fascism" is related also to the aspect of discovering and defining the body whose physicality and aesthetic functions were (and still are) frequently ignored or excluded from the cultural discourse on war and occupation, as was pointed out by Bożena Karwowska. ${ }^{\mathbf{1 0 0}}$ Consequently, this article aims to present a "bodily" perspective on cultural texts concerning the Holocaust.

Translation: Anna Warso

96 Apart from Jerzy Kosiński's and Ignacy Karpowicz's novels, it is worth to mention for instance Andrzej Kuśniewicz's, Eroica (Warszawa: KAW, 1988); Jonathan Littel's, Łaskawe [The Kindly Ones] trans. to Polish by Magdalena Kamińska-Maurugen (Kraków: Wydawnictwo Literackie, 2008); Marian Pankowski's, "Moja SS Rottenführer Johanna," Fraza 4 (1997): 25-35 and Teatrowanie nad świętym barszczem. Wybór utworów dramatycznych (Kraków: Wydawnictwo Literackie, 1995) (the writer claims that "Moja SS Rottenführer Johanna" was based on his own experience, see Piotr Marecki, "Nam wieczna w polszczyźnie rozróba! Marian Pankowski mówi" (Kraków: Korporacja Ha!art, 2011), 115, 118; Marian Pankowski's, ZAuszwicu do Belsen. Przygody (Warszawa: Czytelnik, 2000); Antoni Sobański, Cywil w Berlinie (Warszawa: Sic!, 2006). Discussed by Sławomir Buryła in Tematy (nie)opisane, 311-316, 410-412.

97 Jarosław Mogutin, Сексуальность фашизма <http://mitin.com/people/mogutin/fashism.shtml> accessed August 17, 2014. Cited in: G. Ojcewicz, Skazani na trwanie, 231.

98 For instance, Ilsa-She Wolf Of The SS (USA-Germany, 1975), dir. Don Edmonds; Salon Kitty (France, Italy, Germany, 1976), dir. Tinto Brass.

Przyłuska-Urbanowicz, Pupilla, 195.

100 Karwowska, Ciało. Seksualność. Obozy, 8-9. 